\title{
Pengendalian Jumlah Cacat Produk Pada Proses Cutting Dengan Metode Quality Control Circle (QCC) Pada PT.Toyota Boshoku Indonesia (Tbina)
}

\author{
Selamet Riadi, Haryadi \\ Program Studi Teknik Industri, Universitas Mercu Buana Jakarta \\ e-mail: sriadi_71@yahoo.com
}

\begin{abstract}
ABSTRAK
PT. Toyota Boshoku Indonesia merupakan perusahaan asing yang bergerak dibidang komponen otomotif dengan produk utama yang dihasilkan adalah kursi mobil.Dalam proses pembuatan produk kursi mobil tersebut sering terjadi produk cacat atau kurang sempurna. Untuk meminimalisir terjadinya produk dengan kualitas yang kurang baik, pihak perusahaan melakukan analisa kegiatan dengan menggunakan metode QCC(Quality Control Circle), metode analisa yang dilakukan adalah dengan menggunakan pareto dan fishbone. Dengan kegiatan yang dilakukan diharapkan perbaikan kualitas akan terus berlangsung, dan kualitas semakin membaik. Untuk meminimalisir terjadinya pembuatan barang yang kurang berkualitas pihak perusahaan mewajibkan setiap operator untuk menjaga 3M (Tidak menerima, Tidak membuat, Tidak meneruskan), serta apabila terjadi upnormal pada saat proses berlansung, maka operator diharuskan untuk melakukan tindakan SCW (Stop, Call, Wait).
\end{abstract}

Kata Kunci : Kualitas, $Q C C, 3 \mathrm{M}, S C W$

\section{PENDAHULUAN}

Di era globalisasi ini, perusahaan sangat membutuhkan suatu hasil kerja yang memiliki nilai produktivits yang baik sehingga nilai perusahaan akan meningkat. Perbaikan kualitas dan kuantitas terus dilakukan oleh perusahaan, baik dengan melakukan pengendalian kualitas langsung kepada produk hasil produksi maupun dengan melakukan kegiatan rutin yang menganalisis pengendalian kualitas tersebut.

Kualitas suatu produk merupakan salah satu kriteria yang menjadi pertimbangan pelanggan dalam memilih produk. Kualitas produk juga merupakan indikator penting bagi perusahaan untuk dapat berdiri ditengah ketatnya persaingan dalam dunia industri. Kualitas produk semata-mata ditentukan oleh konsumen sehingga kepuasan konsumen hanya dapat dicapai dengan memberikan kualitas yang baik. Kualitas suatu produk dibangun perusahaan dengan memperhatikan kebutuhan dan keinginan customer karena suatu pabrik industri tidak akan eksis apabila produk yang dibuat atau dipesan tidak sesuai dengan keinginan konsumen. Mempunyai konsumen yang puas akan produk kita merupakan suatu hal yang penting bagi setiap perusahaan. Untuk membangun kepuasan konsumen, identifikasi faktor-faktor kepuasan pelanggan perlu dilakukan.

Menjalankan kualitas suatu produk perlu dilakukan standarisasi yang tepat, agar produk yang dihsilkan sesuai dengan permintaan konsumen. Di PT Toyota Boshoku Indonesia ( TBINA) selaku peruahaan yang bergerak di bidang industri otomotif sangat memperhatikan kualitas dari produknya. Demi kualitas dan kuantitas dari produk yang dihasilkan baik, PT TBINA secar rutin melakukan kegiatan QC, guna mengevaluasi masalah-masalah yang ada di lapangan. Dengan salah satu produk yang dihasilkan ialah kursi mobil, yang dimana didalamnya terdapat material kain yang diproduksi langsung oleh perusahaan tersebut dengan jumlah yang banyak serta memiliki jumlah defect yang cukup banyak juga dari proses pemotongan pola kain untuk kursi tersebut. Data cacat dapat dilihat pada pareto chart di bawah ini 


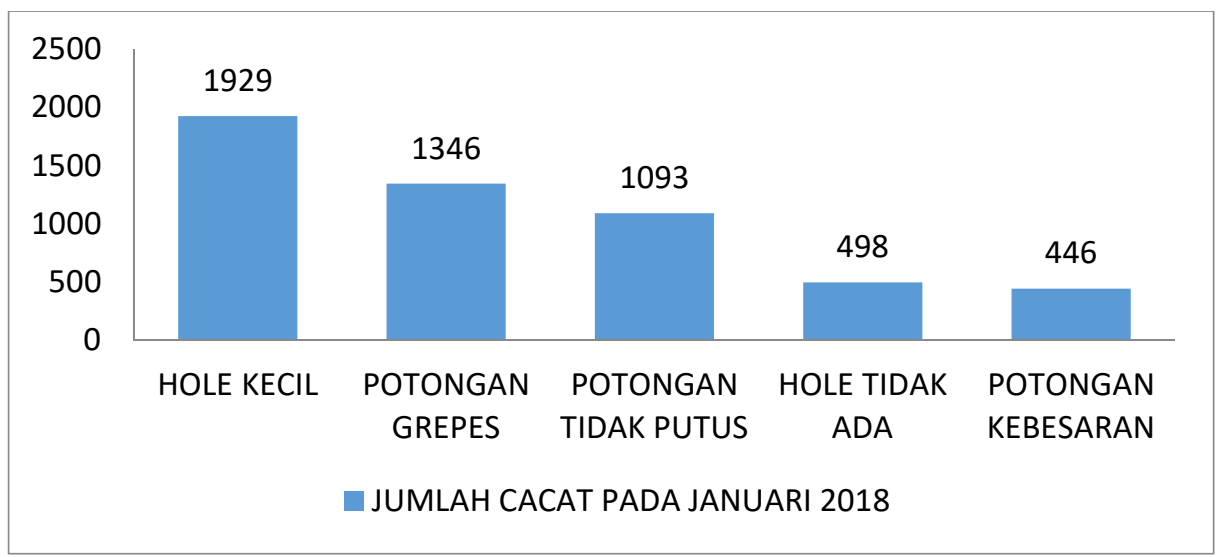

Gambar 1 Pareto chart cacat pada mesin cuting

Metode yang digunakan untuk mengendalikan mutu produk dan mengurangijumlah produk yang mengalami cacatadalah dengan menggunakan metodeQuality Control Circle (QCC), karena Quality Control Circle lebih memfokuskanpada perbaikan (improving), menekan kesalahan, dan meminimalisir produkprodukyang cacat.

\section{Tujuan Penelitian}

Tujuan dari penelitian ini adalah untukmengetahui jenis cacat produk terbesar yang dihasilkan mesin cuting, mengetahui faktor utama penyebab cacat pada mesin cuting, danmenentukan cara agar produk yang dikirim ke proses selanjutnya merupakan produk yang bermutu.

\section{TINJAUAN PUSTAKA}

\section{Kualitas}

Pengertian atau definisi kualitas dapat berbeda makna bagi setiap orang, karena kualitas memiliki banyak kriteria dan sangat tergantung pada konteksnya. Banyak pakar dibidang kualitas yang mencoba untuk mendefinisikan kualitas berdasarkan sudut pandangnya masing-masing. Setiap perusahaan harus menyadari perlunya secara terusmenerus melakukan perbaikan kualitas, perubahan, dan perkembangan bisnis inti (core business) dengan memanfaatkan manajemen kualitas sebagai daya dukung keunggualan bersaing. Menurut Crosby dalam Yamit (2013:7) mengatakan "kualitas sebagai nihil cacat, kesempurnaan dankesesuaian terhadap persyaratan".

Kualitas mencakup produk, jasa, manusia, proses dan lingkungan. Pada sisi yang lain kualitas juga merupakan kondisi yang selalu berubah, misalnya apa yang dianggap merupakan kualitas saat ini mungkin dianggap kurang berkualitas pada masa yang akan datang. Kualitas memiliki makna yang berbeda bagi tiap-tiap orang. Hal ini berkaitan dan tergantung kepada konteks bagaimana kualitas memiliki kriteria serta manfaat dari suatu produk atau jasa yang digunakan oleh masing-masing orang tersebut. Orang yang berbeda akan menilai dengan kriteria yang berlainan pula. Hal inilah yang menyebabkanorang sulit untuk mendefinisikan kualitas dengan tepat. Menurut Kotlerdan Armstrong (2008:272) mengatakan "kualitas produk yaitu karakteristik produk atau jasa yang bergantung pada kemampuannya untuk memuaskan kebutuhan pelanggan yang dinyatakan atau diimplikasikan".

Menurut Goetsch dan Yamit (2013:8) mengatakan "kualitas produk adalah kondisi dinamis yang berhubungan dengan produk, jasa, sumber daya manusia, proses, dan lingkungan yang memenuhi atau melebihi harapan".

Pengendalian mutu pertam kali diperkenalkan oleh Ellias Whitney pada awal abad19. Ia memperkenalkan pengendalian mutu dalam bentuk pengecekan barang-barang yang akan disampaikan pada pelanggan dengan cara memisahkan barang cacat dan barang 
yang tidak cacat, baik dari segi penampilan dan karakteristik agar konsumen merasa puas karena mendapatkan barang dengan kualitas yang baik. Pendekatan ini disebut dengan pengendalian mutu tradisional.

Kualitas adalah convormance to requirement, yaitu yang sesuai dengan yang distandarkan. Suatu produk memiliki kualitas apabila sesuai standar kualitas yang telah ditentukan oleh perusahaan atauSOP. Standar kualitas meliputi bahan baku, proses produksi, dan produk jadi ( Crosby dalam Nasution, 2004). Kualitas adalah suatu kondisi dinamis yang berhubungan dengan produk, manusia/ tenaga kerja, proses dan tugas, serta lingkngan yang memnuhi harapan pelanggan atau konsumen ( Garvin dan Davis dalam Nasution, 2004).

Nasution (2004) menyimpulkan ada beberapa persamaan dalam definisi kualitas, yaitu dalam elemen-elemen sebagai berikut:

a. Kualitas mencakup usaha memenuhi atau melebihi harapan pelanggan

b. Kualitas mencakup produk, jasa mansuia, proses, dan lingkungan

c. kulitas merupakan kondisi yang selalu berubah ( misalnya apa yang dianggap kualitas saat ini mungkin dianggap kurang berkualitas dimasa yag akan datang.)

\section{Metode Quality Control Circle (QCC)}

Quality Control Circle (QCC) disebut juga dengan gugus kendali mutuyaitu sekelompok kecil staf bekerjasama untuk berkontribusi pada peningkatan perusahaan, untuk menghormati kemanusiaan dan membangun kelompok kerja ceria melalui pengembangan potensi staff yang tak terbatas.

Quality Control Circle (QCC) merupakan pendekatan yang banyak dipakaioleh perusahaan-perusahaan dalam melakukan perbaikan kualitas dengan siklus PDCA yang merupakan singkatan Plan-Do-Check-Action. Pendekatan ini diperkenalkan oleh W.E Deming dan W.A Shewhart, seorang pakar kualitas ternama berkebangsaan amerika serikat, sehingga siklus PDCA ini juga dikenal sebagai siklus Deming atau siklus pengendalian. Siklus PDCA umumnyadigunakan untuk mengetes dan mengimplementasikan perubahan-perubahan untuk memperbaiki kinerja produk, proses, atau sistem di masa yang akan datang.

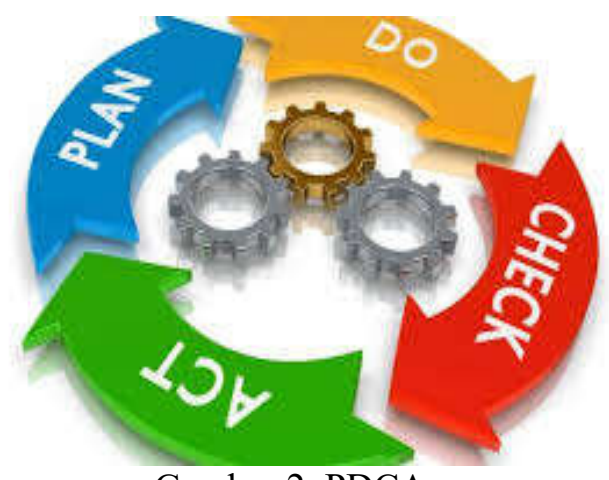

Gambar 2. PDCA

Sumber : Richard, B. Chase, Nicholas,J. Aquilano and Jacobs,F.R.2001

Penjelasan dari tahap-tahap dalam siklus PDCA adalah sebagai berikut (Nasution.M.N, 2005:32):

1. Mengembangkan Rencana (Plan)

Merencanakan spesifikasi, menetapkan spesifikasi atau standar kualitas yang baik, member pengertian kepada bawahan akan pentingnya kualitas produk, pengendalian kualitas dilakukan secara terus-menerus dan berkesinambungan.

2. Melaksanakan Rencana (Do)

Rencana yang telah disusun diimplementasikan secara bertahap, mulai dari skala kecil dan pembagian tugas secara merata sesuai dengan kapasitas dan kemampuan dari setiap personil. Selama dalam melaksanakan rencana harus dilakukan pengendalian, 
yaitu mengupayakan agar seluruh rencana dilaksanakan dengan sebaik mungkin agar sasaran dapat tercapai.

3. Memeriksa atau meneliti hasil yang dicapai (Check)

Memeriksa atau meneliti merujuk pada penetapan apakah pelaksanaannya berada dalam jalur, sesuai dengan rencana dan memantau kemajuan perbaikan yang direncanakan. Membandingkan kualitas hasil produksi dengan standar yang telah ditetapkan, berdasarkan penelitian diperoleh data kegagalan dan kemudian ditelaah penyebab kegagalannya.

4. Melakukan tindakan penyesuaian bila diperlukan (Action)

Penyesuaian dilakukan bila dianggap perlu, yang didasarkan hasil analisis di atas. Penyesuian berkaitan dengan standarisasi prosedur baru guna menghindari timbulnya kembali masalah yang sama atau menetapkan sasaran baru bagi perbaikan berikutnya.

Untuk melaksanakan pengendalian kualitas, terlebih dahulu perlu dipahamibeberapa langkah dalam melaksanakan pengendalian kualitas. Menurut Schroeder.R.G (2007:173) untuk mengimplementasikan perencanaan, pengendalian dan pengembangkan kualitas diperlukan langkah-langkah sebagai berikut :

1. Mendefinisikan karakteristik (atribut) kualitas.

2. Menentukan bagaimana cara mengukur setiap karakteristik.

3. Menetapkan standar kualitas.

4. Menetapkan program inspeksi.

5. Mencari dan memperbaiki penyebab kualitas yang rendah.

6. Terus-menerus melakukan perbaikan.

Yang kemudian dalam perkembangannya lebih dikenal sebagai delapan langkah perbaikan kualitas.

Berikut 8 langkah perbaikan kualitas dalam QCC:

1) Menentukan Tema Masalah.

2) Menyajikan Data dan Fakta.

3) Menentukan Penyebab

4) Merencanakan Perbaikan.

5) Melaksanakan Perbaikan.

6) Memeriksa Hasil Perbaikan.

7) Standarisasi.

8) Merencanakan Langkah Berikutnya.

\section{Seven Tools}

Seven tools merupakan salah satu saran yang digunakan dalam pengendalian proses statistik yaitu berupa tujuh alat pengendalian mutu yang menggunakan teknik statistik. Alat-alat ini meliputi:

\section{a. Lembar pemeriksaan}

Dalam kegiatan produksi diperlukan pemantauan secara sistematis dan teratur yang dilakukan secara tertulis.Untuk melakukan hal ini maka diperlukan lembar pengamatan (check sheet) untuk mempermudah dalam melakukan pengumpulan data terhadap informasi yang diperlukan oleh pengamat.Lembar pengamatan ini berupa data yang hendak diamati, tanggal dan tempat pencatatan, jumlah atau frekuensi data dan identitas pencatat data tersebut. Informasi yang terdapat dalam check sheet ini sedapat mungkin dikelompokkan secara spesifik sehingga memudahkan dalam pengolahan data tersebut.

\section{b. Histogram}

Pengamatan dari suatu karakteristik proses tidak dapat dilakukan hanya dengan melihat pada nilai data yang diambil dari proses tersebut, baik secaraindividu maupun kelompok. Pengamatan dapat dilakukan dengan cara membuat nilai data tersebut dirubah kedalam suatu bentuk histogram agar lebih mudah. 
Histogram adalah suatu penampakan grafik dari data dengan membagi karakteristik data kedalam kelas-kelas atau bagian.Dalam sebuah histogram frekuensi, nilai sumbu vertikal (y) menggambarkan jumlah dari observasi yang dilakukan setiap kelas.Sedangkan untuk sumbu horizontal (x) menggambarkan masing-masing kelas atau bagian.

\section{c. Stratifikasi}

Stratifikasi adalah suatu upaya untuk mengurangi atau mengklasifikasikan persoalan menjadi kelompok atau golongan sejenis yang lebih kecil atau menjadi unsurunsur tunggal dan persoalan. Penguraiannya misalnya dilakukan menurut :

1) Jenis kesalahan

2) Penyebab kesalahan atau kerusakan

3) Lokasi kesalahan atau kerusakan

4) Bahan (material), hari pembuatan, unit kerja, pekerja atau pembuat, penyalur, waktu, lot, dan lain-lain.

Kegunaan dari stratifikasi adalah untuk mengetahui atau melihat secara lebih terperinci pengelompokan faktor-faktor yang akan mempengaruhi karakteristik mutu.

\section{Diagram Pareto}

Diagram pareto memiliki peranan penting dalam proses perbaikan kualitas. Pareto berasal dari nama ekonom italia, Aifredo Pareto yang menggunakan diagram ini pertama kali untuk wilayah pengendalian kualitas dari distribusi kemakmuran.

Prinsip diagram pareto adalah dengan aturan $80 / 20$ yaitu $80 \%$ dan problem (ketidaksesuaian) disebabkan oleh penyebab (cause) sebesar 20\%. Pareto diagram membantu pihak manajemen mengidentifikasi area kritis (area yang paling banyak mengakibatkan masalah) yang membutuhkan perhatian lebih dengan cepat.

Diagram tersebut juga mengidentifikasi hal yang penting, serta alternatif pemecahan yang akan membawa perbaikan secara substansial dalam kualitas. Diagram ini juga memberikan pedoman dalam menempatkan sumber-sumber yang terbatas untuk aktivitas pemecahan masalah. Dengan penggunaan diagram pareto, maka permasalahan akan disusun dalam suatu "kepentingan" yang mengarah pada efek finansial dan permasalahan atau jumlah yang relatif dengan kejadian dalam permasalahan.

Langkah-langkah dalam pembuatan Diagram Pareto menurut Mitra (1993)dan Besterfield (1998), yaitu :

1) Menentukan metode atau arti dalam pengklasifikasian data, misalnya berdasarkan masalah, penyebab, jenis ketidaksesuaian, dan sebagainya.

2) Menentukan satuan yang digunakan untuk membuat urutan karakteristik-karakteristik tersebut, misalnya rupiah, frekuensi, unit, dan sebagainya.

3) Mengumpulkan data sesuai dengan interval waktu yang telah ditentukan.

4) Merangkum data dan membuat rangking kategori data tersebut dari yang terbesar dan yang terkecil.

5) Menghitung frekuensi kumulatif atau persentase kumulatif yang digunakan

6) Menggambar diagram batang, menunjukkan tingkat kepentingan relatif masing-masing masalah. Mengidentifikasi beberapa hal yang penting untuk mendapat perhatian.

\section{Diagram Pencar (Scatter Diagram)}

Diagram pencar adalah suatu diagram yang menggambarkan korelasi (hubungan) dari suatu penyebab/faktor terhadap penyebab/faktor lain atau terhadap karakteristik kualitas.Kegunaan dari diagram pencar adalah untuk melihat ada tidaknya korelasi (hubungan) dari suatu penyebab/faktor yang lain atau terhadap akibat karakteristik kualitas. Cara pembuatan diagram pencar,yaitu :

1. Mengumpulkan data yang diinginkan dan ditabelkan.

2. Menggambar sumbu $\mathrm{x}$ dan $\mathrm{y}$ beserta skala dan keterangannya, kemudian menggambarkan titik-titik data yang sesuai dengan tabel. 


\section{Grafik Pengendali (Control Chart)}

Grafik atau peta pengendali (Nasution, 2006) adalah sebuah grafik atau peta dengan garis batas dan garis-garisnya disebut garis kendali.Tujuan dari grafik pengendali (Montgomery, 1993) adalah untuk menentukan apakah hasil kerja suatu proses dapat dipertahankan pada taraf mutu yang dapat diterima. Adapun penggunaan grafik pengendali adalah:

a. Pemantauan dan pengawasan suatu proses.

b. Pengurangan variabilitas proses.

c. Penafsiran parameter produk atau proses.

Terdapat dua jenis grafik pengendali, yaitu :

a. $\quad$ Grafik pengendali sifat (atribut)

b. Grafik pengendali peubah (variabel)

Grafik pengendali telah mempunyai sejarah penggunaan yang panjang dalam industri di Amerika dan juga dalam industri lepas pantai. Sedikitnya ada lima alas an yang mendasari hal ini, antara lain:

1) Grafik pengendali adalah teknik yang telah terbukti untuk meningkatkan produktivitas.

2) Grafik pengendali efektif dalam pencegahan cacat.

3) Grafik pengendali mencegah penyesuaian proses yang tidak perlu.

4) Grafik pengendali memberikan informasi diagnostik.

5) Grafik pengendali memberikan informasi tentang kemampuan proses.

\section{Kerangka Pemikiran}

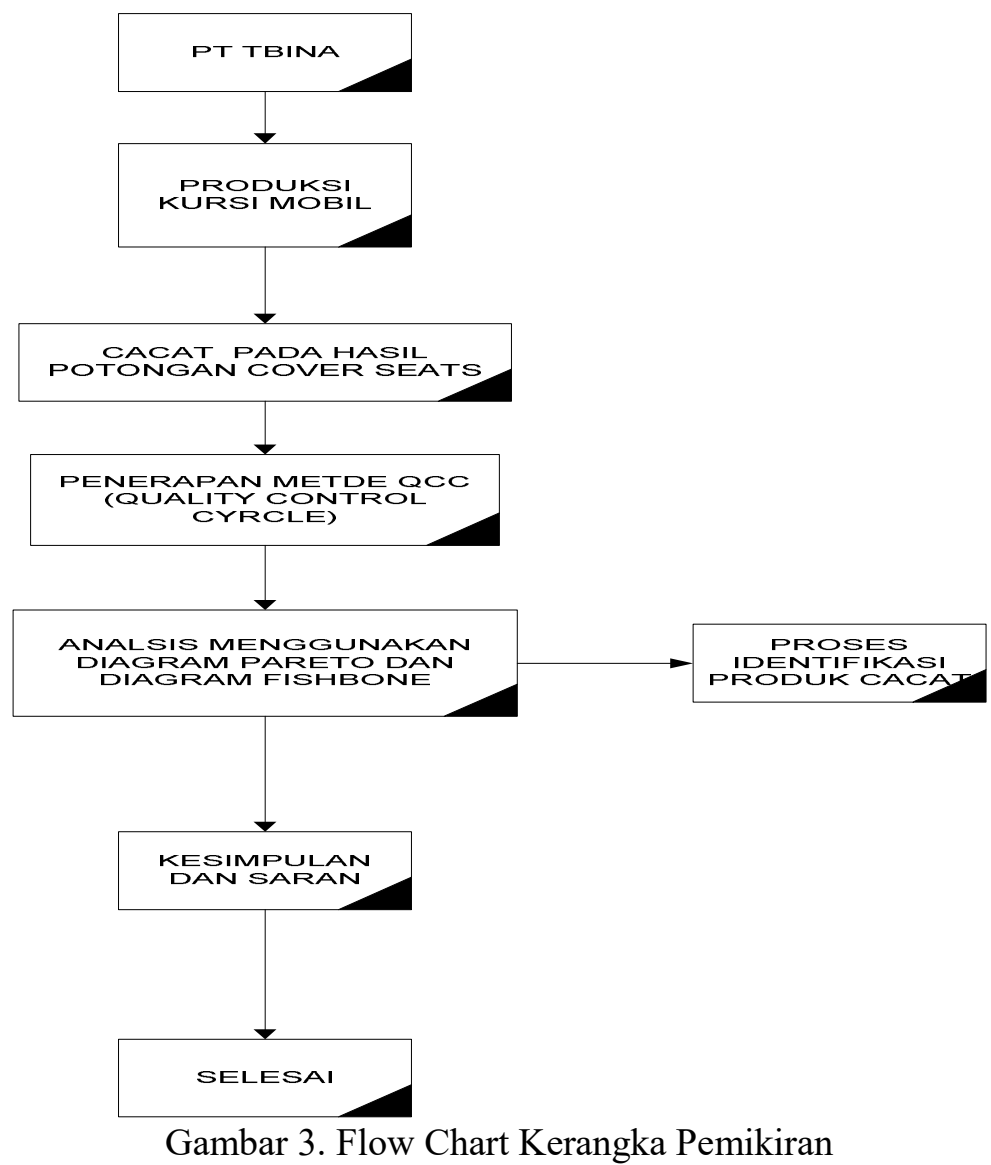

JIM, Vol. 5, No. 1, Februari 2020, pp.57-70 


\section{METODE PENELITIAN}

\section{Tempat dan Waktu Peneliitian}

Penelitian dilakukan di PT Toyota Boshoku Indonesia yang merupakan perusahaaan yang bergerak di bidang manufaktur otomotif dengan produk yang dihasilkannnya yaitu kursi mobil. Penelitian dilangsungkandi departemen produksi Plan 2 Line Cutting untuk proses produksi pola cover kursi mobil. Penelitian ini dilakukan pada Desember 2017 sampai dengan Januari 2018.

\section{Tahapan Identifikasi Awal}

Penelitian diperusahaan tersebut dilatarbelakangi dengan masalah-masalah yang ada dilapangan. Tahap identifikasi awal ini dimaksudkan untuk mengenal gambaran dari masalah pada perusahaan tersebut dengan tepat dan benar dengan kondisi dari lingkungan yang ada. Setelah dilakukan tahap ini, maka tahapanseanjutnya merumuskan masalah yang kemudianmenuangkannya kedalam pokok pikiran penulisan laporan penelitian ini.

\section{Metode Pengumpulan Data}

Metode pengumpulan data ini ialah dengan melakukan pengamtan secara langsung di PT Toyota Boshoku indonesia ( TBINA) dengan teknik pengumpulan data yang digunakan ialah :

1. Penelitian Lapangan

Pengumpulan data dilakukan dengan melakukan peninjauan langsung kelapanga, adapun caranya adalah :
a. Observasi
b. Wawancara
c. Studi Pustaka

Studi pustaka atau literatur diperlukan untuk memperoleh pengetahuan, teori dan wawasan yang mendasar berkaitan dengan pokok bahasan yang akan diungkapkan dalam penelitian ini. Penggunaan literatur tersebut meliputi buku, jurnal, maupun situs internet.

Ruang lingkup kepustakaan yang dipelajari adalah mengenai :

a. Quality Control Circle

b. Management Kualitas

\section{Pengolahan Data}

Dalam melaksanakan pengolahan data ini, digunakan metode QCC ( Quality Control Circle) dengan langkah-langkah sebagai berikut:

1. Menentukan Tema

2. Menetapkan Target

3. Analisis Kondisi Yang Ada

4. Analisis Sebab Akibat

5. Menetapkan Rencana Penanggulangan

6. Penanggulangan

7. Evaluasi Hasil

8. Standarisasi dan Tingkat Lanjut

9. Kesimpulan dan Saran

\section{Analisis dan Pembahasan}

Setelah dilakukan pengumpulan dan pengolah data kemudian akan dilakukan analisis terhadap data. Dengan menjelaskan hasil penelitian yang dilakukan sebelumnya dan sesudah dilakuan perbaikan, yang kemudian akan diketahui seberapa besar hasil dari perbaikan tersebut dengan mengevaluasi.

\section{PENGUMPULAN DAN PENGOLAHAN DATA}

Pengumpulan data cacat pada proses cutting pada periode feb-april 2018, dimana setelah dilakukan pengumpulan data tersebut diperoleh beberapa jenis cacat yang 
dihasilkan pada proses cutting. Adapun data-data yang diperoleh adalah berdasarkan pengamatan harian pada mesin proses cutting.

Tabel 1. Total cacat produksi periode April-Mei 2018

\begin{tabular}{|c|c|c|c|c|c|}
\hline ITEM & APRIL & MEI & JUNI & TOTAL & RATA-RATA \\
\hline PRODUKSI & 52.800 & 59400 & 59400 & 171.600 & 57.200 \\
\hline NG & 2702 & 2211 & 3311 & 8.224 & 2.741 \\
\hline$\%$ NG & $5 \%$ & $4 \%$ & $6 \%$ & $5 \%$ & $5 \%$ \\
\hline TARGET & $2,50 \%$ & $2,50 \%$ & $2,50 \%$ & $2,50 \%$ & $2,50 \%$ \\
\hline
\end{tabular}

Tabel 2. Jenis data barang NG

\begin{tabular}{|c|c|c|c|c|c|}
\hline \multirow{2}{*}{ ITEM DEFECT } & \multicolumn{3}{|c|}{ BULAN } & \multirow{2}{*}{ TOTAL } & \multirow{2}{*}{ RATA" } \\
\cline { 2 - 4 } & APRIL & MEI & JUNI & & \\
\hline HOLE TIDAK PUTUS & 646 & 0 & 1275 & 1921 & 640,33 \\
\hline POTONGAN TIDAK PUTUS & 1410 & 1040 & 1792 & 4242 & 1414,00 \\
\hline GREPES & 0 & 225 & 200 & 425 & 141,67 \\
\hline POLA KEBESARAN & 0 & 0 & 130 & 130 & 43,33 \\
\hline HOLE KECIL & 646 & 946 & 0 & 1592 & 530,67 \\
\hline HOLE GESER & 0 & 397 & 0 & 397 & 132,33 \\
\hline OVER CUT & 0 & 880 & 0 & 880 & 293,33 \\
\hline HOLE KEBESARAN & 0 & 150 & 0 & 150 & 50,00 \\
\hline SECRAT & 0 & 40 & 0 & 40 & 13,33 \\
\hline MATERIAL BERUDUL & 0 & 0 & 140 & 140 & 46,67 \\
\hline TOTAL & 2702 & 2211 & 3397 & 8310 & 2770,00 \\
\hline
\end{tabular}

Dari jumlah cacat produk yang terjadi didapat kontribusi masing-masing cacat output tersebut tiap bulannya.

Dengan diagram pareto kita dapat meengambarkan grafik beserta presentasi kecacatannya berdasarkan jumlah terbanyak :

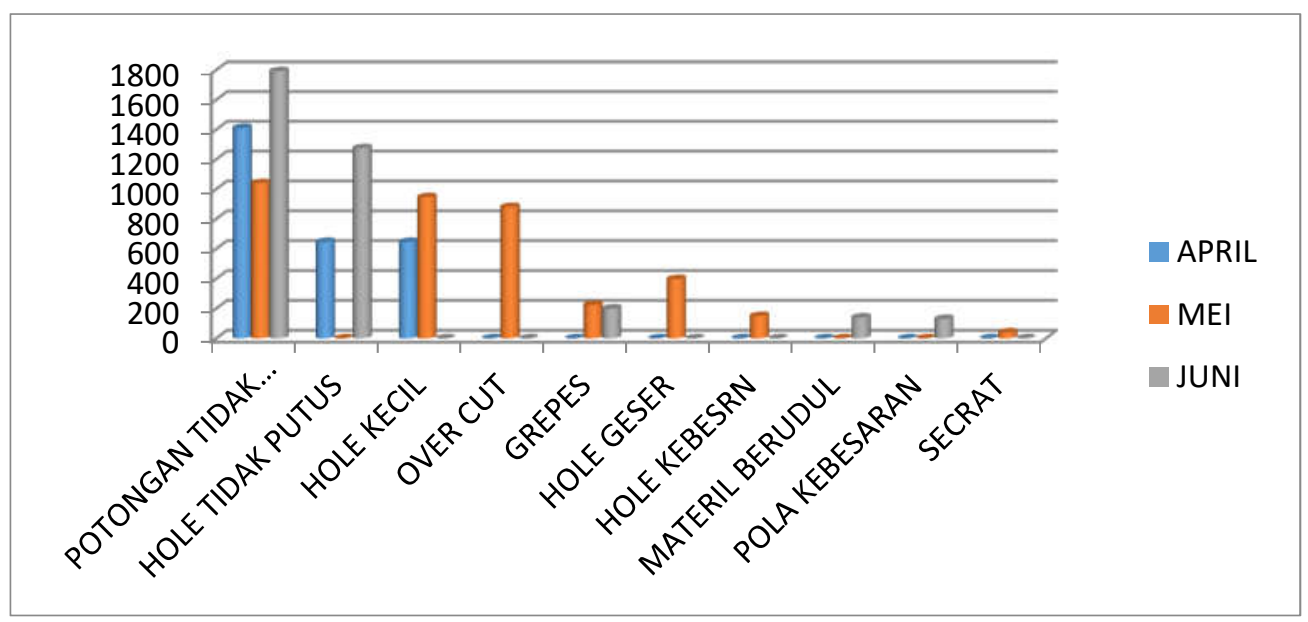

Gambar 4. Grafik cacat dengan pareto chart

Dari data-data tersebut dapat dilihat bahwa kontribusi tertinggi cacat pada proses cutting ialah potongan tidak putus. Meskipun pada hasil tersebut menunjukan bahwa cacat 
tertinggi yang dihasilkan oleh cutting ialah potongan tidak putus, tetapi dalampenulisaninidiputuskan untuk menurunkan cacat tiga tertinggi diantaranya potongan tidak putus, Hole tidak putus, dan Hole kecil dengan alasan bahwa jenis cacat tersebut secara terus menerus terjadi tiap bulannya. Alasan spesifik dapat dilihat di bawah ini :

\section{Spesifik}

Measurable ( terukur)

Archievable ( dapat dicapai)

Reasonable (Beralasan)

Time phased
: Menurunkan 3 jenis cacat tertinggi

: Menurunkan persentase cacat menjadi 2,5\%

: Benchmark internal 3 jenis cacat tertinggi

: 3 Jensis cacat tersebut tertinggi dan continue

: Pertimbangan waktu pencapaian Agustus 2018

\section{Pengolahan Data}

Setelah mengetahui jenis-jenis cacat produk pada proses cutting, selanjutnya pengolahan data dengan mengunakan peta kendali P. Berikut ialah data hasil perhitungan batas kendalai atas (UCL) dan batas kendali bawah (LCL). Dimana data tersebut diambil dari bulan April-Juni, yaitu:

Tabel 3. Data Total Cacat Produk

\begin{tabular}{|c|c|c|c|c|}
\hline No & Bulan & Total Produksi & Total Cacat & Proporsi P \\
\hline 1 & April & 52800 & 2702 & 0,051 \\
\hline 2 & Mei & 59400 & 2211 & 0,037 \\
\hline 3 & Juni & 59400 & 3311 & 0,056 \\
\hline & TOTAL & 171600 & 8224 & 0,144 \\
\hline
\end{tabular}

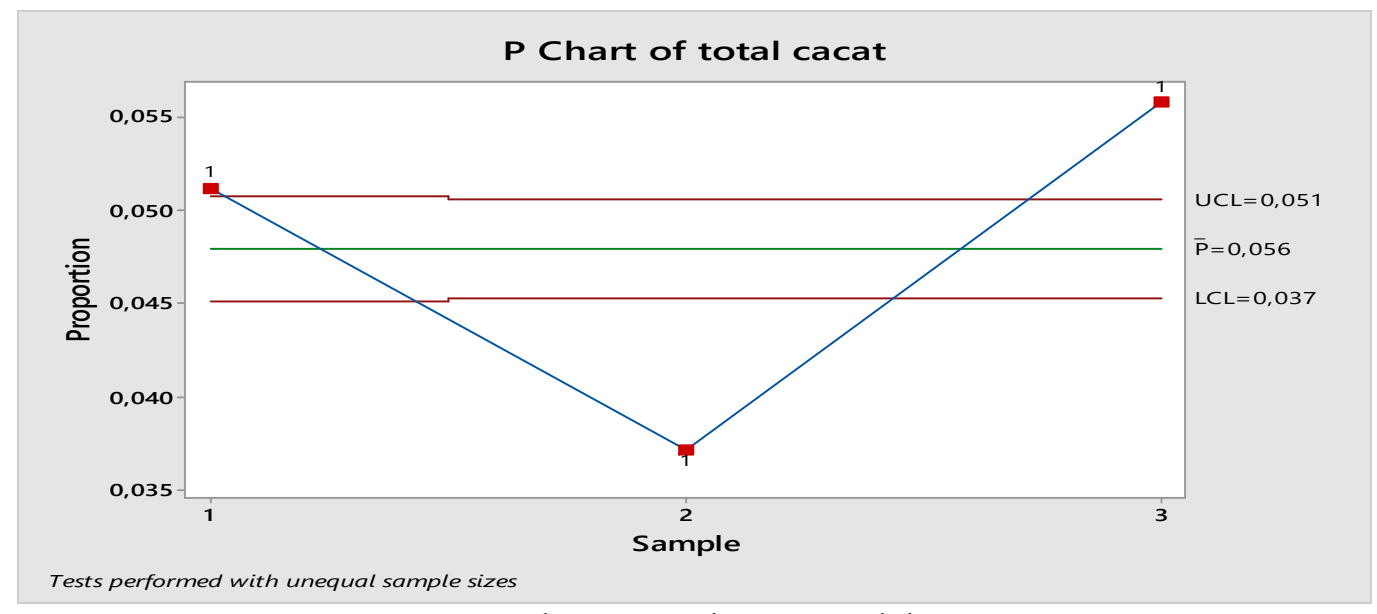

Gambar 5. Total cacat produk

Berdasarkan peta kendali di atas terlihat data berda didalam batas kendali (in statistic cotrol). Selanjutnya ialah menentukan batas kendali atas (BKA) dan batas kendali bawah (BKB) untuk jenis-jenis NG yang terjadi pada proses cutting:

1) Perhitungan untu grafik NG Hole Tidak Putus

Berikut ini adalah hasil perhitungan batas kendali atas ( UCLi) dan batas kendali bawah (LCLi). Dimana NG Hole tidak butus ini mempunyai kontribusi cacat tertinggi pada periode April-Juni 2018.

Tabel 4. NG hole tidak putus dengan UCL dan LCL

\begin{tabular}{|c|l|c|c|c|c|}
\hline No & \multicolumn{1}{|c|}{ Item } & april & mei & juni & Total \\
\hline 1 & NG Hole Tidak Putus & 646 & 0 & 1275 & 1921 \\
\hline & Jumlah Produksi & 52800 & 59400 & 59400 & 171600 \\
\hline & Proporsi P & 0,012 & 0 & 0,021 & 0,034 \\
\hline
\end{tabular}


Berdasarkan hasil dari perhitungan batas kendali atas dan batas kendali bawah, maka data diatas dapat digambarkan dengan peta kendali di bawah ini:

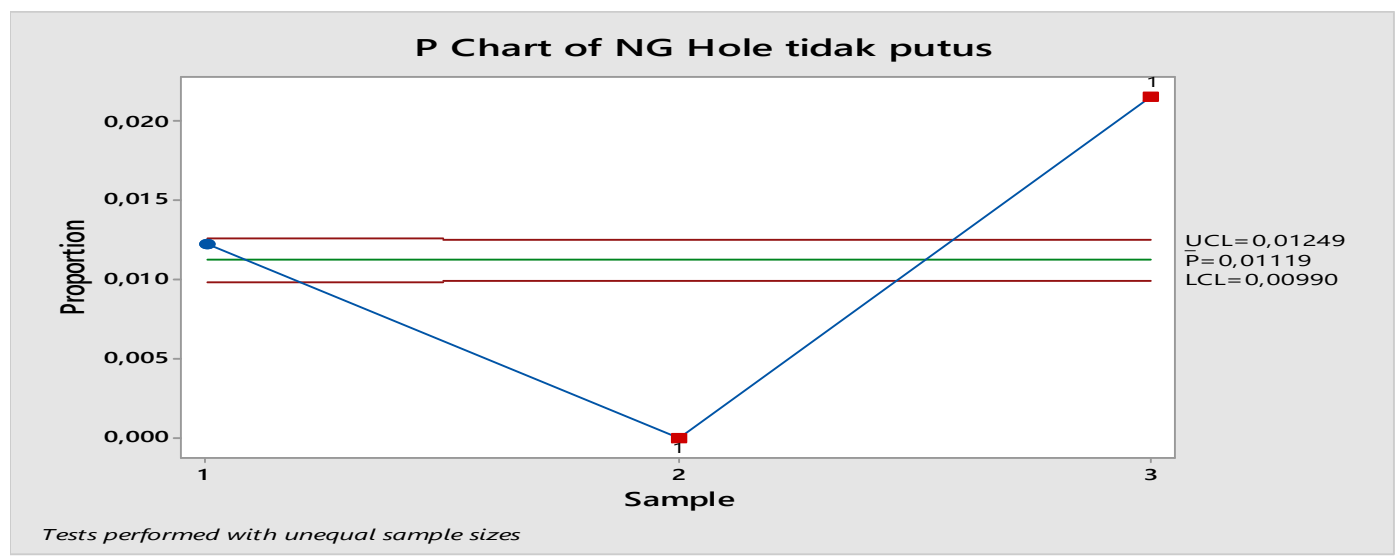

Gambar 6. Grafik UCL\&LCL hole tidak putus

Dari data dan dan gambar tersebut tampak terlihat bahwa seluruh data berada dalam batas kendali, sehingga tidak perlu dilakukan revisi.

2) Perhitungan NG untuk potongan tidak putus

Berikut data hasil perhitungan batas kendali atas (UCL) dan batas kendali bawah (LCL).

Tabel 5. Perhitungan LCL \& UCL Potongan tidak putus

\begin{tabular}{|c|l|c|c|c|c|}
\hline no & \multicolumn{1}{|c|}{ Item } & april & mei & juni & Total \\
\hline 1 & NG potongan tidak putus & 1410 & 1040 & 1792 & 4242 \\
\hline & Jumlah Produksi & 52800 & 59400 & 59400 & 171600 \\
\hline & Proporsi P & 0,027 & 0,0175084 & 0,030 & 0,074 \\
\hline
\end{tabular}

Berdasarkan hasil perhitungan batas kendali atas (UCL) dan batas kendali bawah (LCL), maka dapat dilihat peta kendali sebagai berikut:

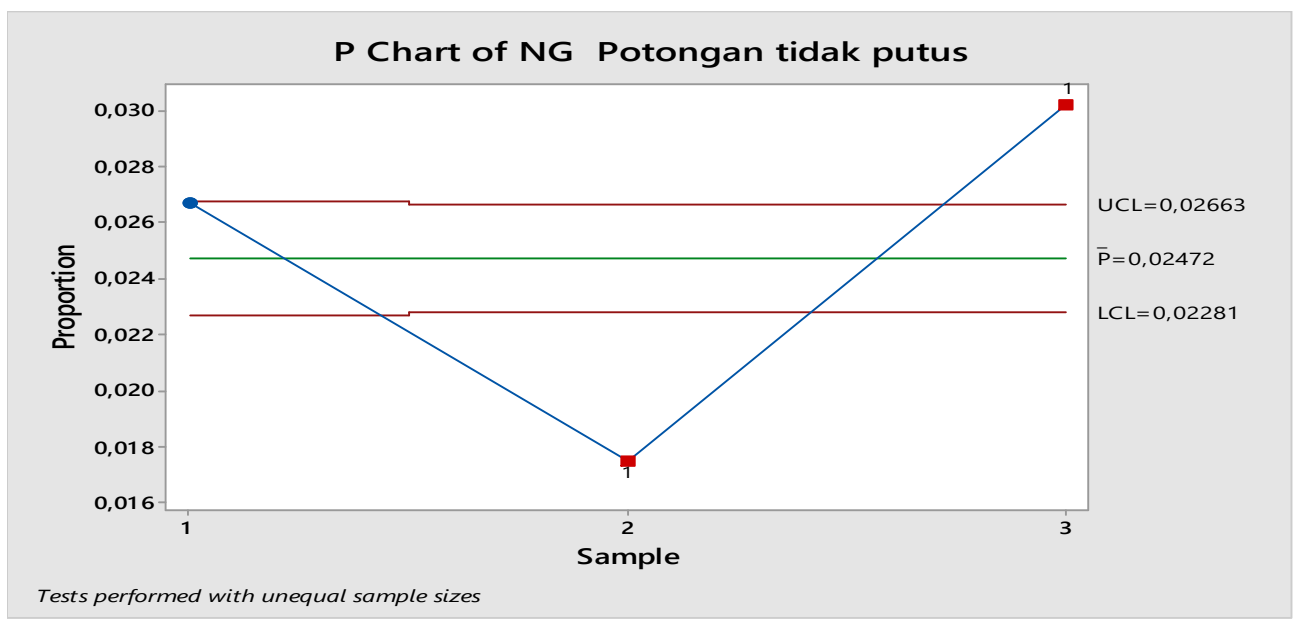

Gambar 7. Grafik LCL\&UCL potongan tidak putus

Berdasarkan gambar tersebut terlihat bahwa data berada dibawah batas kendali, sehingga tidak perlu dilakukan revisi. 
3) Perhitungan NG untuk Hole kecil

Berikut data hasil perhitungan batas kendali atas(UCL) dan batas kendali bawah (LCL).

Tabel 6. Perhitungan LCL\&UCL hole kecil

\begin{tabular}{|c|l|c|c|c|c|}
\hline no & \multicolumn{1}{|c|}{ Item } & april & mei & juni & Total \\
\hline 1 & NG Hole kecil & 646 & 946 & 0 & 1592 \\
\hline & Jumlah Produksi & 52800 & 59400 & 59400 & 171600 \\
\hline & Proporsi P & 0,012 & 0,0159259 & 0,000 & 0,028 \\
\hline
\end{tabular}

Berdasarkan hasil dari perhitungan batas kendali atas (UCL) dan batas kendali bawah (LCL), maka dapat dilihat gambar batas kendali sebagai berikut:

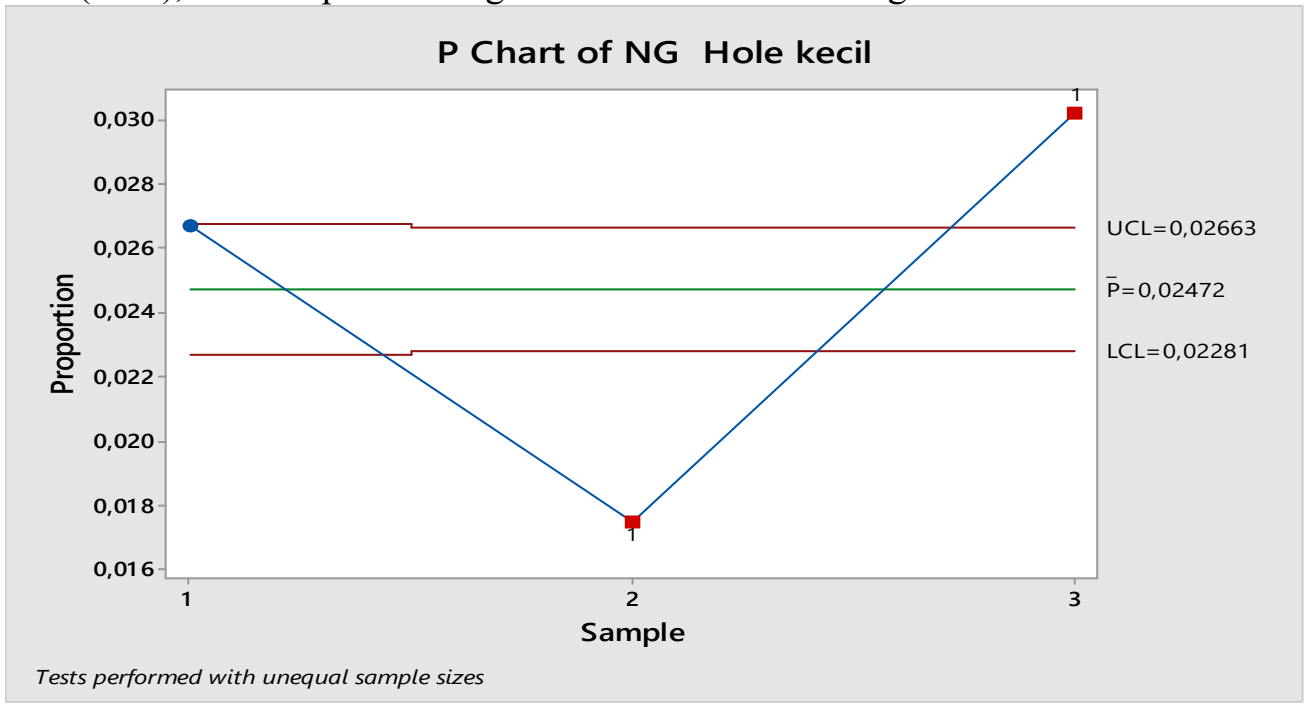

Gambar 8. Grafik UCL\&LCL hole kecil

Dari data tabel tersebut tampak bahawa seluruh data berada dalam batas kendali, sehinggga tidak perlu dilakukan revisi.

\section{ANALISA DATA \\ Menjalankan Prinsip 3M}

Pada dasarnya operator dalam melakukan proses produksi yang dilakukan adalah dengan memepercepat kerja namun tidak setidikit pula yang mengindahkan darikualitas produk yang telah dibuat sebelum dikirim ke proses selanjutnya. Disinilah prinsip $3 \mathrm{M}$ sebenarnya harus benar-benar dijalankan dalam melakukan proses produksi untuk mencapai produk yang bermutu. 3M adalah singkatan dari, Tidak Membuat, Tidak Menerima, dan Tidak Meneruskan suatu produk. Untuk lebih jelasnya dibawah ini akan di paparkan secara lebih rinci agar dapat memahami prinsip 3M, yaitu:

a. Tidak Membuat

Proses produksi yan tinggi terkadang membuat operator menjadi lengah dalam memperhatikan kualitas dari produk yang dibuat pada saat proses berlangsung. Kualitas produk sangat penting untuk dijaga agar kualitas terjamin saat dikrim ke customer. Didalam prinsip Toyota terdapat $3 \mathrm{M}$ salah satunya adalah tidak membuat. Maksudnya adalah operator memastiakan bahwa barang atau material yang dibuat merupakan barang yang telah dipastikan terjamin kualitasnya, jika tidak maka harus dilakukan penanganan terkait kesalahan tersebut.

b. Tidak Menerima

Prinsip yang kedua adalah tidak menerima. Maksud disini ialah operator yang sedang melakukan proses produksi harus memastikan kondisi barang yang telah diterima dari proses sebelumnya ataupun dari distributor dengan mengecek terlebih dahulu material 
sebelum dilakukan proses. Operator harus teliti dalm melakukan produksi, karena barang yang sudah dikerjakan atau dikirm dari proses sebelumnya belum tentu baik kualitasnya. Oleh dari itu hal penting dalam menjaga kualitas produk yang dibuat adalah dengan memastikan material atau barang yang diterima berkualitas baik.

c. Tidak Meneruskan

Pada prinsip dapat dilihat pada sistem assembly, dimana proses ini berkelanjutan dengan mengrim perbagiaan sesuai dengan pos masing-masing. Jika pada suatu pos ditemukan ada kesalahan atau cacat pada proses sebelumnya dengan barang yang diterima, maka yang harus dilakukan adalah melakukan SCW/ Stop Call Wait, yaitu dengan behenti melakukan aktifitas baran tersebut, lalu panggil atasan yang bertugas pada bagian tersebut, dan setelah menunggu instruksi dari atasan. Apabila pada hasil yang telah dibuat tersebut telah dicek ternyata hasilnya ok maka teruskan, teteapi jika hasilnya tidak standar maka jika masih bisa diperbaiki dilakaukan refair sesuai standar, namun jika tidak bisa dilkukan perbaikan maka harus dipisahkan ke tempat barang cacat dan harus musnahkan.

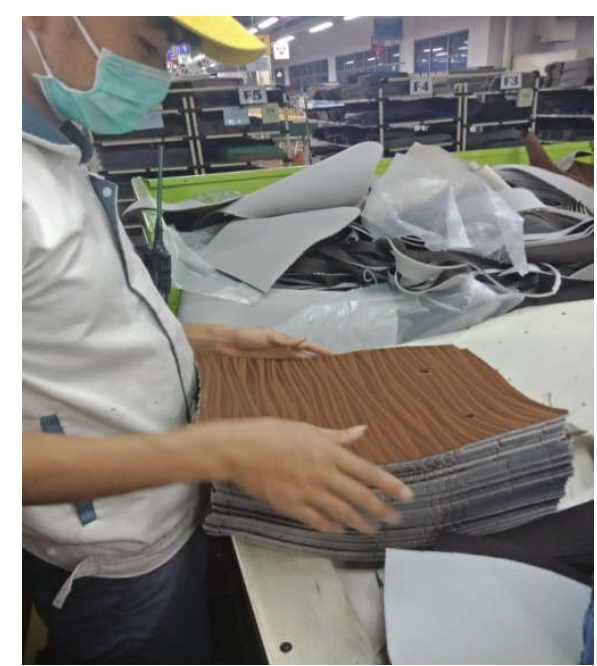

Gambar 9. Pengecekan material hasil potong oleh QC

\section{KESIMPULAN DAN SARAN \\ Kesimpulan}

Berdasarkan hasil pengolahan dan analisis pembahasan yang telah dilakukan sebelumnya, maka didapatkesimpulan sebagai berikut:

1. Jenis cacat yang terjadi pada mesin cuting pada dasarnya memiliki beragam jenis, namun ada beberapa jenis cacat yang sering timbul ataupun terjadi setiap bulannya dengan jumlah cacat terbesar dengan data diambil dari 3 bulan terakhir, diantaranya adalah potongan tidak putus 4242, hole tidak putus dengan 1921 pcs, hole kecil dengan 1592 pcs.

2. Dari beberapa jenis cacat yang diketahui pada data sebelumnya yang telah diambil dan dianalisis, diketahui dengan menggunakan diagram fishbone hal yang menyebabkan terjadinya cacat tersebut, diantarnya ialah:

a. Karena pengaruh dari mesin. Hal ini dapat dilihat dari jenis cacat yang terjadi, misalnya pada potongan tidak putus, jika pisau yang digunakan sudah over cut, atau terkikis, maka hasilnya memungkinkan terjadinya cacat tersebut.

b. Standar gelaran sangat berpengruh terhadap hasil yang diperoleh. Jika material dengan tebal $5 \mathrm{ft} /$ feet maka standar tebal gelaran tidak boleh lebih dari 15 tumpuk,jika lebih dari standar tersebut hal yang mungkin terjadi adalah cacat seperti, hole kecil dan sebagainya.

c. Operator yang mengoperasikan mesin cutting harus mampu mengetahui jenis dan bahan dari material, serta mampu untuk melakukan penyetingan mesin dengan baik 
sesuai dengan material yang dipotong.

3. Menjalanakan SCW (stop call wait) bagi setiap operator yang melakukan proses produksi sangat penting, agar tidak terjadi hal yang berkelanjutan pada proses sealanjutnya. Dengan menjalankan prinsip tersebut, apabila terjadi kondisi upnormal pada mesin maka operator wajib untuk melakukan SCW, agar kualitas yang dihasilkan bermutu. Prinsip $3 \mathrm{M}$ menjadi cara agar barang yang dikirim ke proses selanjutnya adalah barang yang bermutu baik. Dengan melakukan 3M operator telah menjaga keamana kualitas dari produknya dan juga proses dari langkah selanjutnya. Cacatakan berkurang, serta produktifitas akan membaik.

\section{Saran}

Beberapa saran yang dapat digunakan untuk perbaikan agar tidak terjadi atau meminimalisir jumlah cacat yang banyak terjadi pada proses cutting, diantaranya:

1. Melakuan prefentive maintenance secara rutin dilakukan, agar mesin tetap dalam kondisi yang baik.

2. Pisau merupakan alat utama dalam melakan proses potong, maka perlu dilakukan pergantian pisau dalam waktu per sift untuk menjaga kualitas hasil yang dipotong baik.

3. Seluruh karyawan pada lini tersebut hendakanya harus menyadari bahwa adanya aktifitas selain daripada kerja rutin yang dilakukan,yaitumelakukan kegiatan QCCdengan rutin. Agar seluruh elemen team tahu permasalah yang ada pada bagian tersebut.

4. Dari kegiatan analisis dengan menggunakan QCC ini ternyata diketahui standar itu sangat penting dalam melakukan proses produksi. Oleh karena itu, meningkatkan kesadaran terhadap karyawan untuk selalu menggunakan standar yang telah dibuat harus dilakukan,halini bertujuan untuk mendapatkan hasil yang maksimal.

5. Atasan atau kepala bagian harus terus memonitordanmemberikan masukan setiap hari untuk menjaga kualitas dengan baik dengan menjalankan 3M dan melakukan SWC (stop call wait) bila ditemukan cacat atau ketidak sesuaian.

6. Terus tingkatkan produktivitas, namun harus menyadari pentingnya kualitas.

\section{REFERENSI}

Sulaeman. 2014. Analisa Pengendlaian Kualitas Untuk Mengurangi Produk Cacat Speedometer Mobil Dengan Menggunakan Metode QCC di PT INS. Jurnal Pasti,VIII (1), 71-95.

Yosan, R.B. 2017. Analisis Kualitas Produk Dab Korelasinya Terhadap Tingkat Kepuasan Konsumen Dengan Metode Statistical Process Control. Sinergi, Vol.21(3), 231237.

Astini, R. 2015. Menanggulangi Kelebihan Pemakaian Coklat Pada Produksi Wafer XX Dengan Metode QCC Di PT XYZ. Jurnal Pasti VIII (3), 326-339.

Juran, J.M., dan F.M. Gryna.1993, Quality planning and analysis : From product Development Throureght Use. Singapure : MC Graw. Hill Co.

Scheward, W.A. 1939. Statistic Methods from the Viewpoint of Quality Control. Washington D.C.:Departemen of Agriculture.

Snyder, M. 1994. Topics In Just In Time Management. Singapore: Allyn and Bacon.

Gazperz, Vincent. 1998. Production Planning and Inventory Control Berdasarkan Pendekatan Sistem Terintegrasi MRP II dan JI. Jakarta: Gramedia Pustaka Utama.

Assauri, S. 2008. Manajemen Produksi dan Operasi. Jakarta: Fakultas Ekonomi Universitas Indonesia.

Haming, M, \&Mahmud. N. 2007. Manajemen Produksi Modern (Operasi manufaktur dan Jasa). Jakarta : Bumi Aksara.

Kurniawan Fajar, Modul Kuliah Pengendalian Kualitas, Universitas Mercu Buana, Jakarta.

Ramford. D. 2003. The Use of Quality Management Tools And Techniques : Study of Aplication In Everyday Situations. International Journalof Quality \& Reliability Management Vol 22 No 4, 239-245.

Martynova, O. 2011. Asfect Of Product Quality Control : Determination Of 
QualityComponen And Product Quality Factor. International Journal Of KhersonNational Technical University.Vol 2, 1804-4158.

Pantouvakis. 2016. Exploring Total Quality Management aplication under uncertainty: A research agenda for the shipping industryTotal Quality Management TQM. Vol 18, 496-512.

Dunn, W.B. 2017. Quality assurance and quality control process: summary of methabolomicscomunityquestionaire. Quality Assurance.Vol. 10, 13-50.

Sharif, S.H. 1999. Student quality control circle : a case study on student paarticiption in the quality control circle at the faculty of business and management. Quality Control Cyrcle (QCC), Vol.24 (2), 0260-2938.

Samman, R.A. 2016, Continous Quality Improvement program-part, survey critical analysis and future research direction JIT (Just In Time). Vol. 50 (2) 250-278. 